Volume 7

Number 3 Oil \& Gas Survey

Article 15

$5-12-2021$

\title{
California Community Choice Aggregation Law \& Regulation
}

Ryan M. F. Baron

RYAN.BARON@bbklaw.com

Glen Price

Glen.Price@bbklaw.com

Benjamin Bodell

BENJAMIN.BODELL@bbklaw.com

Follow this and additional works at: https://scholarship.law.tamu.edu/journal-of-property-law

Part of the Oil, Gas, and Mineral Law Commons, and the Property Law and Real Estate Commons

\section{Recommended Citation}

Ryan M. Baron, Glen Price \& Benjamin Bodell, California Community Choice Aggregation Law \& Regulation, 7 Tex. A\&M J. Prop. L. 480 (2021).

Available at: https://doi.org/10.37419/JPL.V7.I3.15

This Student Article is brought to you for free and open access by Texas A\&M Law Scholarship. It has been accepted for inclusion in Texas A\&M Journal of Property Law by an authorized editor of Texas A\&M Law Scholarship. For more information, please contact aretteen@law.tamu.edu. 


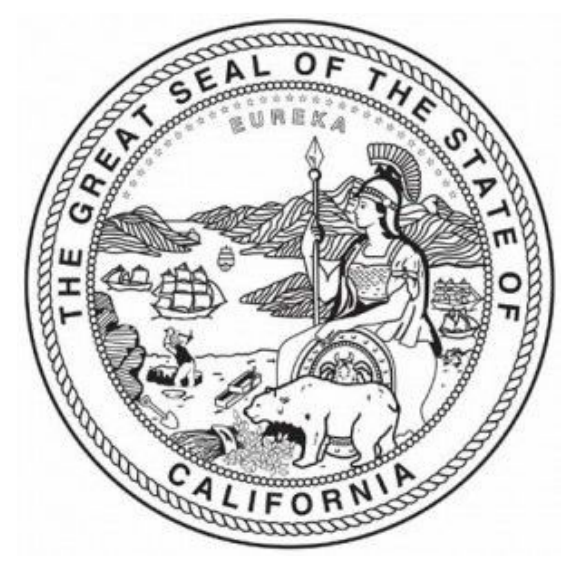

\title{
California Community Choice Aggregation LaW \& REGULATION
}

\author{
Ryan M. F. Baron, Glen Price, and Benjamin Bodell ${ }^{\dagger}$
}

\section{INTRODUCTION}

The purpose of this special topic is to provide a summary of the laws and regulations associated with the development of Community Choice Aggregation ("CCA") in California and the growing impact of CCA in the California energy market.

In 2000-2001, California experienced a devastating energy crisis due to deregulation, capped electricity prices, a shortage of supply, and market manipulation, resulting in multiple large-scale blackouts and extreme prices. In response to the crisis, the California Legislature passed several bills to bring order to California's energy markets. The Legislature provided an energy procurement alternative-community

DOI: https://doi.org/10.37419/JPL.V7.I3.15

tRyan M. F. Baron is a partner at Best Best \& Krieger LLP providing strategic counsel on utilities regulation, administrative law, environmental law, and project development matters. Glen Price is a partner at Best Best \& Krieger LLP with experience advising public agency and private clients in connection with capital projects and renewable energy development. Ben Bodell is an associate at Best Best $\&$ Krieger LLP advising on energy and environmental law matters. 
choice aggregation ${ }^{1}$ - that allows California cities and counties, and groups of cities and counties through separate local government agencies known as "joint powers authorities," to opt their residents and commercial and industrial businesses out of receiving retail electricity from the investor owned utility ("IOU") and directly control and provide retail power at the local level. ${ }^{3}$ This legislation sparked a significant movement by local governments in California to provide retail electricity to their residents and businesses without having to form municipal utilities and take over the IOU transmission and distribution system.

CCA allows local agencies to aggregate the electric load of its jurisdiction and provide electricity to those residents, businesses, and municipal accounts within the CCA's municipal boundaries. Under the CCA model, local government entities take over the retail function of an electric utility by procuring and generating power and providing it to ratepayers, while IOUs continue to provide electric transmission, distribution, utility line maintenance, and metering and billing services. The CCA model offers a new entry point into the California energy landscape for cities and communities while providing consumer choice, ${ }^{4}$ competitive rates, local control, economic development, and climate-related benefits by increasing the development of renewable energy, particularly in a market that has been traditionally controlled by vertically integrated, natural monopolies.

Recent innovations in energy technology and resultant lower costs, as well as incremental policies encouraging renewable energy resource adoption, have led California on a path towards a diversified market for consumer electric services. ${ }^{5}$ The California Public Utilities Commission ("CPUC") estimated that within the next decade over $85 \%$ of retail load in California will be served by alternative sources. ${ }^{6}$

1. AB 117, 2001-2002 Leg. Sess. (Ca. 2002); see Cal. Pub. Util. Code $§ 366.2$. Community choice aggregation is more popularly known as community choice energy.

2. CAL. Gov'T CODE $\S 6500$ (2012) (California Joint Exercise of Powers Act).

3. Cal. Pub. Util. Code $\S 366.2$ (2020).

4. CAL. PuB. UTIL. CoDE $\S 366.2$ (c)(13) (2020). Consumer choice is provided by allowing the CCA customer the ability to opt out of service and return to IOU service.

5. Rooftop solar, Community Choice Aggregators (CCAs) and Direct Access providers (ESPs), which are effectively non-IOU unbundled providers, served over $25 \%$ of California's retail electric load in 2019 and 2020.

6. Robert Walton, California PUC Staff: Non-Utility Suppliers Could Serve $85 \%$ of Load by Mid-2020s, UtilityDive (May 17, 2017), 
California faces numerous challenges and opportunities in developing a coherent plan to integrate and manage the growth of CCAs and diversified energy provision, including renewable procurement rules, resource adequacy requirements, and consumer protection.

\section{EVOLVING REGULATORY FRAMEWORK}

In 2010, Marin Clean Energy (MCE) launched the first CCA in California, ${ }^{7}$ and Sonoma Clean Power followed suit in $2014 .^{8}$ These and other CCAs demonstrated a model that has the potential to yield substantial benefits to communities and customers, including reduced prices and higher rates of renewable resource utilization. As a result, CCA formation increased dramatically across California in recent years, with many new CCAs launching throughout the state. Twenty-one CCAs now exist in the territory of the three major IOUs in California, ${ }^{9}$ with many additional communities planning formation or investigating membership. ${ }^{10}$ As of September 2020, these twentyone CCAs account for nearly ten million customer accounts, an increase of approximately $40 \%$ since the end of $2017 .{ }^{11}$

The rapid departure of IOU customers to CCAs led the CPUC to adopt CCA registration timelines and requirements that CCAs participate in state energy planning proceedings to ensure grid reliability and the fair allocation of capacity obligations. Other issues also exist, such as the increasing volatility of utility "exit fees" and challenges with CCAs obtaining sufficient credit for long-term energy transactions.

https:/www.utilitydive.com/news/california-puc-staff-non-utility-suppliers-couldserve-85-of-load-by-mid-/442897/ [https://perma.cc/B5V5-SNK5].

7. Alexandra McGee, Marin Clean Energy Startup Timeline and Funding, MCE (February 8, 2016), https://www.mcecleanenergy.org/wpcontent/uploads/2016/01/MCE-Start-Up-Timeline-and-Initial-Funding-Sources-106-14-1.pdf [https://perma.cc/XK3N-K2N9].

8. Sonoma Clean Power Officially "Flips the Switch", SONOMA Clean POWER (May 1, 2014), https://sonomacleanpower.org/uploads/documents/Sonoma-CleanPower-Begins-Serving-Customers-050114-web.pdf LFWR].

9. This includes Pacific Gas \& Electric, Southern California Edison, and San Diego Gas \& Electric. 2010-2020: A Decade of CCA in California, CALCCA (May 1, 2020), httpsa://cal-cca.org/celebrating-10-years-of-cca-in-california/ [https://perma.cc/9WST-YNR6].

10. CALCCA, https://cal-cca.org/ [https://perma.cc/SFG2-BP9T] (last visited Jan. 19, 2020).

11. $I d$. 


\section{A. Renewable Resource Integration \& California Regulatory Policy}

While deregulation coupled with market fragmentation has the potential to lead to another energy crisis, ${ }^{12}$ the CPUC has taken an aggressive stance towards CCA regulation through a broad interpretation of its duty to regulate CCAs under the Public Utilities Code. California Public Utility Code Section 366.2 forms the statutory framework for CCA regulation by the CPUC and pronounces that CCAs have the independent authority to procure electricity for its jurisdictional customers. ${ }^{13}$ However, a CCA must submit an implementation plan to the CPUC, which demonstrates the ability to provide reliable, universal service in conformance with all state laws. ${ }^{14}$ Furthermore, the CPUC is vested with the duty to prevent cost shifting and promote ratepayer indifference by ensuring that CCA customer departure does not increase costs for customers that remain with the IOU and that the IOUs do not improperly pass along costs to CCA customers that should stay with the IOUs. ${ }^{15}$

\section{Resource Adequacy and CCA Implementation}

The CPUC's resource adequacy mandates require all load-serving entities (electricity providers), which includes CCAs, to procure sufficient capacity to supply electricity to all of their customers during periods of maximum electricity demand for the upcoming year. Because electricity demand (including peak demand) fluctuates, electricity providers must ensure that a cushion amount of electricity (a "reserve margin") is capable of being generated at any given time, even though it might not be needed. The purpose of resource adequacy is to provide an additional safety net in the event of an unforeseen spike in power demand. Thus, all electricity providers must obtain capacity commitments that are greater than peak electricity demand. ${ }^{16}$

12. See e.g., Michael Colvin, Diane I. Fellman, Raisa Ledesma Rodriguez, CPUC StafF, CAlifornia Customer Choice: An Evaluation of REGULATORY FRAMEWORK OPTIONS FOR AN EVOLVING ELECTRICITY MARKET (Rohimah Moly ed.) (2018).

13. CAL. PUb. UTIL. CODE $\S 366.2(a)$ (2019).

14. $\$ 366.2(\mathrm{c})$

15. $\S 366.2(\mathrm{a}),(\mathrm{c})(2019)$.

16. Pub. Utilities COMM’n, Decision 04-01-050, at pp. 20-27, Order Instituting RULEMAKING TO ESTABlish POLICIES AND COST RECOVERY MEChanisms FOR Generation Procurement AND RENEWABle RESOURCE DEVElopment (2001) (CPUC Policy Requires LSE's to secure Capacity commitments $15 \%$ greater than peak load.) 
The surge of CCA formation since 2016 has shifted load from IOUs to CCAs in rapid fashion. ${ }^{17}$ In addressing the rapid expansion of CCAs, the CPUC now requires CCAs to submit load forecasts and year ahead resource adequacy filings if they plan to serve new or additional load in the subsequent calendar year. ${ }^{18}$ The CPUC also mandated a longer resource adequacy procurement cycle, which requires all electricity providers to procure a certain percentage of local resource commitments up to three years ahead at the beginning of each cycle. This long-term procurement cycle, in which the CPUC proposes to utilize an independent buyer, will presumably impose additional costs on all electricity providers and strip CCAs of some of their independent energy procurement authority. ${ }^{19}$

\section{Energy Procurement and Resource Planning Regulations}

\section{a. Renewables Portfolio Standard Procurement Plans}

CCAs must file Renewables Portfolio Standard ("RPS") procurement plans with the CPUC that demonstrate compliance with the state's renewable energy targets under Senate Bill 350. CCA RPS procurement plans must include project status and progress updates, notice of potential compliance delays, and an assessment of portfolio diversity as it relates to grid integration and under-utilization of

17. See Jeff St. John, How Community Choice Aggregation Fits Into California's Clean Energy Future, GREENTECH MEDIA (Sept. 12, 2018), https://www.greentechmedia.com/articles/read/how-community-choice-

aggregation-fits-into-californias-clean-energy-future [https://perma.cc/WF5SXDQG].

18. CPUC Proposal Would Require CCAs to Coordinate with Resource Adequacy Program, California Public Utilities Commission News Blog (Feb. 5, 2018), https://www.cpuc.ca.gov/cpucblog.aspx?id=6442455641\&blogid=1551 [https://perma.cc/W3KZ-MZXH].

19. Pub. Utilities COMM'N, Decision 18-06-030, at 32, Order Instituting Rulemaking to Oversee the Resource Adequacy Program, Consider Program REFINEMENTS, AND Establish ANNUAL LOCAL AND FleXible PROCUREMENT OBLIGATIONS FOR THE 2019 AND 2020 COMPLIANCE YEARS (2018) ("Weighing both the concerns and the potential benefits of moving to a central buyer system, we believe that a central buyer system - for at least some portion of local RA - is the solution most likely to provide cost efficiency, market certainty, reliability, administrative efficiency, and customer protection . . . central procurement of system or flexible RA may be considered in future years."); MEGAN Somogyi ET AL., New CPUC Regulation of Community Choice Aggregators, LEAGUE OF CALIFORNIA CitiES 15 (2018) https://www.cacities.org/ResourcesDocuments/Member-Engagement/Professional-Departments/CityAttorneys/Library/2018/AC-PPTS-and-Papers/9-2018-AC\%3B-Somogyi-NewCPUC-Regulation-of-Communit.aspx [https://perma.cc/7Y89-V2M5]. 
renewable resources. ${ }^{20}$ Plans should also demonstrate how RPS portfolios optimize cost consideration, value, and risk for the benefit of customers. ${ }^{21}$

\section{b. Integrated Resource Plans}

CCAs must comply with the long-term energy planning mandates under SB 350 by filing an integrated resource plan ("IRP") with the CPUC. ${ }^{22}$ The CPUC's integrated resource planning process takes a long-term (ten years) planning approach to system needs (reliability needs of the overall electric system), local needs (reliability needs specific to areas with transmission limitations), and flexibility needs (such as the resources needed to integrate renewables). The Commission requires IRP plans to ensure long-term portfolio optimization that balances greenhouse gas reduction with cost and reliability considerations. In a recent determination, the CPUC held that CCAs must substantively comply with state IRP requirements. ${ }^{23}$

\section{B. Additional Legal and Financial Considerations}

\section{The Power Charge Indifference Adjustment}

On October 11, 2018, the CPUC unanimously adopted a precedential decision reforming the power charge indifference adjustment ("PCIA") methodology. The PCIA is a methodology used by the IOUs to determine the "exit fee" or charge customers of CCAs and other departing load customers pay to cover the generation costs acquired before the customers' change in service provider. State law requires that customers of IOUs and CCAs remain financially

20. CAl. Pub. Util. Code $§ 399.13$ (2020); Pub. Utilities Comm’n, Decision R.15-02-020, at 9, ORDER InSTITUTING RULEMAKING TO CONTINUE IMPLEMENTATION AND ADMINISTRATION, AND CONSIDER FURTHER DEVELOPMENT, of CALIFORNIA RENEWABLES PORTFOLIO STANDARD PROGRAM (2018).

21. Id.

22. Pub. Utilities COMm'N, Decision 18-02-018 at pp. 25-29, Order INSTITUTING RULEMAKING TO DEVELOP AN ELECTRICITY INTEGRATED RESOURCE PlanNING FramewORK AND TO COORDINATE AND REFINE LONG-TERM PROCUREMENT PlanNING REQUIREMENTS (2018) (“We maintain that our authority and responsibility over CCA planning is considerably broader than the CCAs and their representatives argue.").

23. Id. at 26. Moreover, the Commission determined that if a CCA does not meet the statutory or Commission requirements, it has the authority to order long-term procurement commitments, and to assign costs of non-performance to meet the identified needs for renewable integration in accordance with Public Utility Code Section 454.51. 
indifferent when a customer departs for the service of another electricity provider. Currently, customers that choose to take service with a CCA pay a charge on their electric bill to offset the costs that the IOU has incurred on that customer's behalf. This practice prevents cost shifting and ensures that remaining IOU-bundled customers are indifferent to and do not incur additional costs due to departing load. The PCIA also prevents IOUs from unfairly shifting costs to CCA customers.

The IOUs' PCIA-eligible portfolios are made up of both capital expenditures for retired nuclear and fossil fuel generation as well as long-term contracts for renewable energy executed during the infancy of the California renewables market. Increased market scale and technological advancements caused a steep drop in the cost of renewable resources in the past decade. Older contracts (and their related PCIA costs) come at a substantial mark up from today's market prices.

In a unanimous decision, the five CPUC Commissioners adopted a PCIA calculation methodology that allows IOU legacy generation assets, like Diablo Canyon nuclear power plant and hydroelectric facilities, to be included in the PCIA methodology. The PCIA decision also included true-up mechanism for PCIA collections based on the actual net costs of IOU resources and rejected a ten-year limit on recovery of post-2002 UOG assets, which would have limited IOU cost recovery. The adopted PCIA will result in hundreds of millions of dollars in additional costs to CCA customers.

Creditworthiness is also a substantial hurdle to long-term energy procurement for CCAs, and Credit Rating Agencies have taken note of the risks created by the PCIA decision. In 2020, CCAs will need to procure a significant amount of power through long-term contracts of ten or more years, as required by state law, to hedge against uncertainty and potential market volatility. With the recent PCIA decision squeezing out some of the savings to the customer along with credit constraints resulting from the COVID-19 international pandemic, it may be difficult in the short-term for some CCAs to generate the reserve margins required to establish a favorable credit rating and obtain credit at reasonable rates. 